\title{
The Development of Teaching Media Based on PREZI Application at Fluid Dynamic Subject
}

\author{
Mustika Wati, Sri Hartini, Dian Novita, Saiyidah Mahtari \\ Physics Education Program, Faculty of Teacher Training and Education \\ Universitas Lambung Mangkurat \\ Banjarmasin, Indonesia \\ mustikawati_pfis@unlam.ac.id
}

\begin{abstract}
The development of science and technology creates a variety of media that can present data. One of them is the Prezi application. The strength of Prezi application is that it can be used online. This research aimed to describe: (1) the validity of teaching media using Prezi, (2) practicality of teaching media using Prezi, (3) the effectiveness of teaching media using Prezi. This research is a research and development which refers to the model of ADDIE development. Trial subjects were students at class XI IPA 3 SMA Negeri 9 Banjarmasin. Data were obtained through the sheet of media validation, sheet of feasibility teacher activities, and learning outcomes test. The research results showed (1) the teaching media is valid category, (2) practicality of teaching media is very good, and (3) the effectiveness of teaching media is effective. The conclusion of the research is that the teaching media are feasible and effective to use.
\end{abstract}

Keywords-Teaching Media, Prezzi Application, Fluid Dynamic

\section{INTRODUCTION}

Educational activities are related to teaching and learning process. The learning process is essentially a process of communication, which is a process to convey the message of the source of the message via a specific channel or medium to the message recipient. Media, message, source of the message, and the recipient are the components of the communication process [1]. Media in the learning process have a quite important meaning because in these activities obscurity of material submitted can be clarified by using the media as an intermediary. Differences in learning styles, interests, limitations of senses power, intelligence, disability or geographic distance barriers, distance, time and others can be helped and overcome with the use of education media [2]. However, in fact teachers rarely use the media.

Most teaching and learning activities in schools rarely use instructional media, including in SMA Negeri 9 Banjarmasin. Based on the facts in the field observed by investigators undergoing the practice field experience at SMA Negeri 9 Banjarmasin, it was found that the school has a fairly complete educational facilities as well as internet networks, computers, and projectors which were actually able to support learning to be easier and more efficient. Yet, its utilization is still not optimal. In addition to the problem of not maximized utilization of the facilities, the learning model used is always the same model without a variety of media. The media are simple and conventional, such as blackboards, textbooks, and others. The use of less varied media causes students to become bored and show a lack of attention.

One way to maximize these facilities is by using interesting instructional media which have never been seen to understand lesson particularly in Physics subject that requires motivation and innovation in the teaching-learning process so that students do not get bored easily while studying. The development of instructional media usage is now leading to elearning based media. One of the e-learning based media is prezi media that have superiority to accommodate learning styles. Prezi media can be programmed to display the media in the form of visual, audio, or animation. A new presentation software tool, Prezi, sets itself apart by employing a new metaphor, the "infinite canvas" and the zooming user interface. Prezi's infinite canvas is a theoretically endless twodimensional surface upon which text, graphics, video clips, and other visual aids are arranged. Prezi's interface allows for smooth and seamless zooming of the canvas, supporting views as wide or as narrow as the presenter desires [3]. Zooming User Interface ZUI offer new techniques for managing multiple versions of a presentation, providing interactive presentation navigation, and distinguishing levels of detail. These zoomable presentations may also offer several cognitive benefits over their commercial slide show counterparts [4].

The availability and utility of this instructional media are expected to help teachers cope with media utilization of innovative learning and help students access the material more easily. Prezi gives greater possibilities to improve the learning process to be more effective and efficient, so students' learning outcomes can be improved. Prezi was a more effective instructional medium for knowledge acquisition compared with traditional instruction [5]. Conducted a cultural comparison between the United States and Norway regarding Prezi application in group projects and determined that Prezi changed the traditional thinking process of students in preparing presentation slides [6]. Surveyed the experiences of college students in using Prezi in the classroom and indicated that students reported that Prezi might improve their learning outcomes [7] .

Based on the abovementioned description, we need media that can enhance student motivation. The purpose of this research in general was to produce learning media based on 
proper Prezi application in learning. The specific objective of this research was to describe the validity, practicality, and effectiveness of the developed media.

\section{METHOD}

Research and development was the research type conducted in this research. This research developed a teaching media based on Prezi applications in class XI at the second semester on dynamic fluid topic. The steps in this development were the research development model of ADDIE (Analysis, Design, Development, Implementation, Evaluation). The learning media was tried out in the classroom using the design of pretest and post-test group.

The subjects in the trials were students of class XI IPA 3 at SMA Negeri 9 Banjarmasin. The research was conducted from January to July 2016. The research setting was SMA Negeri 9 Banjarmasin located at Jl. Tatah Bangkal Luar RT. 32 No. 1.

Data analysis techniques in this research were assessments of the developed media. The data included the results of the module validation; the results of the feasibility of teacher activity; student learning outcomes from test.

\section{RESULTS AND DISCUSSION}

\section{A. Validation Results of Prezi Teaching Media}

Table 1 shows that the validation of the teaching media.

TABLE I. RESULTS of THE VALIDATION of THE TEACHING MEDIA

\begin{tabular}{|c|c|c|c|c|c|}
\hline \multirow{2}{*}{$\begin{array}{c}\text { Aspects of } \\
\text { assessment }\end{array}$} & \multicolumn{2}{|c|}{$\begin{array}{c}\text { Score of } \\
\text { validation }\end{array}$} & $\begin{array}{c}\text { P Per } \\
\text { Aspect }\end{array}$ & Average & Category \\
\cline { 2 - 6 } & $\boldsymbol{1}$ & $\mathbf{2}$ & & & \\
\hline \multirow{2}{*}{$\begin{array}{c}\text { Variations in } \\
\text { presentation }\end{array}$} & 3 & 3 & 6 & 3 & Good \\
\cline { 2 - 6 } & 3 & 3 & 6 & 3 & Good \\
\hline \multirow{2}{*}{\begin{tabular}{c} 
Feasibility \\
\cline { 2 - 6 }
\end{tabular}} & 4 & 4 & 8 & 4 & $\begin{array}{c}\text { Very } \\
\text { good }\end{array}$ \\
\cline { 2 - 6 } & 3 & 3 & 6 & 3 & Good \\
\hline \multirow{2}{*}{$\begin{array}{c}\text { Completeness } \\
\text { of media }\end{array}$} & 3 & 4 & 7 & 3,5 & $\begin{array}{c}\text { Very } \\
\text { good }\end{array}$ \\
\cline { 2 - 6 } & 3 & 3 & 6 & 3 & Good \\
\hline \multirow{2}{*}{\begin{tabular}{c} 
Design Media \\
\cline { 2 - 6 }
\end{tabular}} & 3 & 3 & 6 & 3 & Good \\
\hline $\begin{array}{c}\text { The overall } \\
\text { appearance }\end{array}$ & 3 & 3 & 6 & 3 & Good \\
\hline Total & 32 & 34 & 63 & 31.5 & \\
\hline Average & 3.1 & 3.2 & & 3.15 & Valid \\
\hline Reliability & 0.62 & 6 & 3 & Good \\
\hline
\end{tabular}

Teaching media used was a presentation teaching media (Prezi) as an application that can create a design with a zooming slide presentation to support learning in order to achieve the learning objectives. The teaching media was validated by two validators from academician and practitioner.
Validation of the teaching media consists of variations in presentation, feasibility, completeness of media, design media and the overall appearance. Based on Table 1, the validation results of the media showed the validity level at good category. The reliability coefficient of teaching media was 0.62 with good category. The validation results indicate that the media is proper to be used and reliable. Effective learning requires good planning[8]. Good planning includes methods and media to be used in the learning process.

\section{B. The Practicality of Teaching Media}

The practicality of teaching media can be seen in the feasibility of teacher activities in content and observed by two observers. Table 2 shows that the feasibility results of teacher activities.

TABLE II. FEASIBILITY RESULTS of TEACHER ACTIVITIES

\begin{tabular}{|c|c|c|c|c|c|c|}
\hline \multirow{2}{*}{ Aspects } & \multicolumn{4}{|c|}{ Average for Each Meeting } & Average & Category \\
\cline { 2 - 7 } & 1 & 2 & 3 & 4 & & \\
\hline$\sum$ Overall & 73.0 & 72.0 & 70.0 & 74.5 & 72.38 & \\
\hline Average & 3.65 & 3.60 & 3.50 & 3.73 & 3.62 & Very good \\
\hline $\begin{array}{c}\text { Overall } \\
\text { reliability }\end{array}$ & 0.78 & 0.79 & 0.80 & 0.88 & 0.81 & Very good \\
\hline
\end{tabular}

Table 2 shows that the average of the feasibility of teacher activities in each meeting is in the range of 3.5 to 3.73. This result is classified as a very good category. Thus, it can be concluded that learning with Prezi teaching media has been performed very good.

Overall the developed teaching media can be considered practical in terms of the feasibility of teacher activities. The overall average of reliability was 0.81 . Thus, for the reliability in the feasibility of teacher activities in the whole meeting was stated in reliable caegory. The used sheets of teacher activity feasibility have consistency and steadiness in terms of measuring the practicality of the developed teaching media and can be used repeatedly to measure the same thing. Practicality means easy implementation, easy examination and includes instructions that can be administered and implemented by people [9].

\section{The Effectiveness of Teaching Media}

The effectiveness of teaching media was investigated through achievement test. Student learning outcomes in this study were obtained through a pre-test and post-test and calculated using normalized test and the value of 0.63 .

TABLE III THE EFFECTIVENESS of TEACHING MEDIA

\begin{tabular}{|c|c|c|}
\hline Total Students & Average Gain & Category \\
\hline 32 & 0.67 & $\begin{array}{c}\text { Moderate } \\
\text { (Effective) }\end{array}$ \\
\hline
\end{tabular}


From the analysis, it can be seen that most of the students were in moderate category, so that learning can be stated to be effective. Effectiveness refers to the level of success in achieving the intended purpose [10]. Most of the students reported that Prezi was an effective learning tool for enhancing their learning process [11].

Based on the results of validation, the practicality and effectiveness of teaching media, the developed teaching media base on Prezi are feasible and effective in learning. Teaching media have an effect on student learning outcomes. Prezi might improve students learning outcomes [5][6][7].

\section{CONCLUSIONS}

The results of the development of teaching media are: (1) the teaching media is valid category, (2) practicality of teaching media is very good, and (3) the effectiveness of teaching media is effective. Based on these results, the developed of teaching media base on Prezi Application are feasible and effective for used in the learning process at the fluid dynamic.

\section{ACKNOWLEDGMENT}

The authors thank to Faculty of Teacher Training and Education, Universitas Lambung Mangkurat due to the funding of BO-PTN 2016 for this research.

\section{REFERENCES}

[1] R. H. Sadiman, Anung and Rahardjito, Media Pendidikan: Pengertian, Pengembangan dan Pemanfaatannya, Jakarta: Rajawali Press, 2003.

[2] A. Puspitasari, L. Rakhmawati, "Pengembangan e-book interaktif pada mata kuliah Elektronika Digital," Jurnal Pendidikan Elektro, vol. 2, pp. 537-543, 2013

[3] J. Bean, "Pressentation software supporting visual design displaying spatial relationships with a zooming using interface," in In Professional Communication Conference (IPCC), Orlando, 2012.

[4] L. Good and B. B. Bederson, "Zoomable user interfaces as a medium for slide show presentation," Information Visualization, vol. 1, no. 1, pp. 35-49, 2002.

[5] P. N. Chou, C. C. Chang and P. F. Lu, "Prezi versus powerpoint: the effects of varied digital presentation tools on students' learning performance," Computers and Education 91, pp. 73-82, 2015.

[6] S. Brock and C. Brodahl, "A Tale of two cultures: cross cultural comparison in learning the prezi presentation software tool in the US and Norway," Journal of Information Technology Education, vol. 12, pp. 95-119, 2013.

[7] P. Virtanen, J. Myllarniemi and H. Wallander, "Diversifying higher education: facilitating ways of learning," Campus-Wide Information Systems, vol. 30, no. 3, pp. 201-211, 2013.

[8] A. Arsyad, Media Pembelajaran, Jakarta: Rajawali Pers, 2015.

[9] A. J.vam den, R. Branch, K. Gustafson, N. Nieven and T. Plomp, "Principles and Methods of Development Research," in Design Approaches and Tools in Education and Training, Dordrecht, Kluwer Academic Publishers, 1999, pp. 1-14.

[10] Widoyoko, Evaluasi Program Pembelajaran, Yogyakarta: Pustaka Pelajar, 2009.

[11] C. Conboy, S. Fletcher, K. Russell and M. Wilson, "An evaluation of the potential use and impact of prezi, the zooming editor software, as a tool to facilitate learning in higher education," Innovations in Practice, vol. 7, no. 1, pp. 31-45, 2012. 